\title{
FAILURE TO REPATRIATE FUNDS IN FOREIGN CURRENCY FROM ABROAD AND MODERN ISSUES OF CURRENCY REGULATION
}

\author{
Oleg A. Stepanov, Denis A. Pechegin \\ The Institute of Legislation and Comparative law \\ under the Government of the Russian Federation, Department of criminal, \\ criminal procedural law; judicial system
}

\begin{abstract}
The monetary policy of the European Union has recently undergone changes that cannot but have an impact on national economies. Thus, starting in 2018, the new rules for calculating the liquidity of banks and the ratio of borrowed funds to assets will come into full force in the European Union. Several large banks in France, dissatisfied with the policy of the European Central Bank (ECB), even appealed to the European Court of Justice for a change in the rules. Meanwhile, this is another step towards establishing financial transparency and strengthening the banking system. Meanwhile, at the international level, uncertainty still remains over issues of currency and legal responsibility, which is largely due to various legal regulations. In most cases, companies that carry out foreign economic activity violate currency legislation. At the same time, civil measures may not be sufficient to protect the normal functioning and development of the domestic foreign exchange market.
\end{abstract}

Keywords: monetary responsibility, the Russian Federation, the Czech Republic, the European Central Bank, repatriation of funds, currency regulation, virtual currency.

\section{INTRODUCTION}

The monetary regime in the Russian Federation is regulated by Federal Law No. 173-FZ of December 10, 2003 (as amended on July 3, 2016) "On Currency Regulation and Currency Control" (hereinafter - Fe deral Law No. 173-FZ). According to the preamble, the purpose of Federal Law No. $173-\mathrm{FZ}$ is to ensure the enforcement of state monetary policy, as well as the stability of both the currency of the Russian Federation and the domestic foreign exchange market of the Russian Federation as factors in the progressive development of the national economy and international economic cooperation.

Monetary policy of the Czech Republic has exactly the same objectives, and the favorable functioning and development of the country's economy also largely depend on the stability of the domestic foreign exchange market. ${ }^{1}$

According to FxPro analysts' reports, economic growth in Europe has accelerated to a slightly higher trend, and the ECB is on the verge of abandoning the ultra-soft monetary policy in the di-

1 SALVATORE, D., RENGIFO, E., OZSOZ, E. Dollarization as an Investment Signal in Developing Countries: The Case of Croatia, Czech Republic, Peru, Slovak Republic and Turkey. Available at <https://ssrn.com/abstract=1272092>.[q. 201805-29]. 
rection of neutral and is further preparing for tightening. Since the ECB adheres to inflation targeting quite rigidly, and the trade and budget balance has long been in favor of the euro, discipline in monetary policy could turn into a new long-term trend of strengthening the euro. ${ }^{2}$ It should be mentioned that this is not only a European trend. Thus, there have been major problems with the economy of Argentina because of double-digit inflation every year since $2002 .{ }^{3}$ Of course, when public money and the country's central bank notes are unable to provide individuals with the quality and availability they demand of their money, people feel free to switch to other options, which include not only digital currencies, but also the U.S. dollar, etc. That is why the new President of Argentina Mauricio Macri made a move to strengthen monetary control. ${ }^{4}$

Under these conditions, completely different mechanisms for protecting the domestic foreign exchange market can be used, including criminal law measures. The article examines the doctrinal and practical aspects of the functioning of laws on liability for non-repatriation of funds and modern issues of currency regulation.

\section{FAILURE TO REPATRIATE FUNDS IN FOREIGN CURRENCY FROM ABROAD}

An analysis of the legal regulation of foreign systems allows us to consider our own national experience through the lens of international practice, which forces us to analyze and evaluate this problem from a different angle, in a new aspect, with an enriched understanding of the essence of the problem. ${ }^{5}$

For nearly all countries with a developed market economy, protection of currency and currency assets by criminal law is typical, but only from the point of view of their falsification and forgery. This approach applies, for instance, in Austria, Germany and Switzerland. There is complete freedom of foreign exchange operations and there is no criminal liability for operations related to the movement of foreign exchange capital. Thus, the criminal laws of Germany do not provide a generally accepted and precise definition characterizing criminality in the area of currency circulation. Furthermore, the movement of capital to and from the country is practically unlimited, as a result of which there are no norms in the legislation establishing liability for crimes in the sphere of currency regulation and currency control.

In the criminal legislation of these countries there are no criminal prohibitions covering the export of currency assets outside the country and their non-repatriation, since such movement is carried out by free settlements under foreign economic transactions and investments. Currency control in these countries is based on other principles. In France, to make a foreign economic transaction or investment to an offshore jurisdiction one must pay all taxes first. In Japan, one must have a special license when such foreign transaction will be made outside an authorized bank or by an unusual method.

Available at <https://news.rambler.ru/business/37423029-kurs-evro-podnimetsya-bolee-chem-na-50/?utm_source= twsharing\& utm_medium=social $>$. [q. 2018-05-29].

Available at $<$ http://data.worldbank.org/indicator/NY.GDP.DEFL.KD.ZG?locations=AR>. [q. 2018-05-29].

4 RASKIN, M., YERMACK, D. Digital Currencies, Decentralized Ledgers, and the Future of Central Banking. Available at $<$ https://ssrn.com/abstract=2773973>. [q. 2018-05-29].

5 BLANPAIN, R., ENGELS, Ch. (eds.). Comparative Labour Law and Industrial Relations in Industrialized Market Economies. The Hague : Kluwer Law International, 2001, p. 4. 
In contrast, countries with another type of economy (a transitional economy) provide special liability for failure to repatriate funds in foreign currency from abroad. In all the criminal codes of the countries of the former Soviet Union there are provisions that establish a criminal prohibition on the production or sale of counterfeit money or securities, their illegal transfer across the customs border, and non-repatriation of funds from foreign countries in foreign currency (the Criminal Code of Azerbaijan - Art. 208, the Criminal Code of Belarus - Art. 225, the Criminal Code of Georgia - Art. 217, the Criminal Code of Kazakhstan - Art. 213, the Criminal Code of Tajikistan - Art. 287, the Criminal Code of Uzbekistan - Art. 178, the Criminal Code of Ukraine - Art. 207).

However, the scale and significance of fraudulent actions in economic activity are increasing every year. Therefore, there is a need for common mechanisms to counter currency crimes.

The monetary regime in the Russian Federation is defined “... as an aggregate of legal means with the common subject of its regulation being the sphere of currency relations that determine such behavior of the subjects of these relations, under which the protection of the national currency and the normal functioning and development of the domestic foreign exchange market are guaranteed". 6

But "the development of offshore markets in a foreign currency poses several challenges to a central bank's responsibility for maintaining monetary stability. An offshore market in a foreign currency can increase the difficulty of defining and controlling the money supply in that currency. Equally, an offshore market in a foreign currency can pose a challenge to measuring and controlling bank credit. If monetary policy is based to some extent on the control of money or credit, then the effect of offshore use of the currency on money or credit should be factored in when setting monetary or credit targets or monitoring ranges"7.

That is why in the Russian Federation in accordance with Art. 19 of Federal Law No. 173-FZ, when carrying out foreign trade activities, residents are required to provide the following by the deadlines stipulated in foreign trade agreements (contracts):

- the receipt from non-residents in their bank accounts in authorized banks of foreign currency or Russian Federation currency which is payable in accordance with the conditions of these agreements (contracts) for goods transferred to non-residents, work performed for them, services rendered to them and information and results of intellectual activity, including exclusive rights thereto, which have been transferred to them;

- the return to the Russian Federation of funds which were paid to non-residents for goods which have not been imported into the customs territory of the Russian Federation (have not been received in the customs territory of the Russian Federation), work which has not been performed, services which have not been rendered and information and results of intellectual activity, including exclusive rights thereto, which have not been transferred. ${ }^{8}$

Failure to comply with this obligation entails administrative and criminal liability stipulated by the laws of the Russian Federation. Administrative liability is stipulated for officials and legal entities, and consists in imposing an administrative fine. Criminal liability is regulated by Art. 193 of the Criminal Code of the Russian Federation. Let us dwell on this in more detail.

6 KUCHEROV, I. Currency Law of Russia (Academic Lecture Course), 2011, p. 38.

DONG, H., MCCAULEY, R. Offshore Markets for the Domestic Currency: Monetary and Financial Stability Issues. Available at $<$ https://ssrn.com/abstract=1699740>. [q. 2018-05-29].

8 English version of the Federal Law 173-FZ. Available at $<$ http://russiaindiabusiness.com/Federal_Law_On_Currency_ Regulation_and_Currency_Control.pdf $>$. [q. 2018-05-29]. 
Evasion of obligations to repatriate funds in foreign currency or in the currency of the Russian Federation from abroad consists in failure to enroll or repatriate, in accordance with the established procedure, funds in foreign currency or in the currency of the Russian Federation in a large amount from one or several non-residents to the accounts of a resident in an authorized Bank or a resident's accounts with banks located outside the territory of the Russian Federation to the resident in accordance with the terms of foreign trade contracts (contracts) for goods transferred to non-residents, work performed for them, services rendered to them, information and results of intellectual activity transferred to them, including exclusive rights thereto.

First of all, it is necessary to clearly define what is meant by the term "currency", i.e., with the subject of currency crimes. The subject of crimes related to the non-repatriation of funds are currency and currency assets. At the same time, Federal Law No. 173-FZ deals with currency terms and currency assets, but does not contain an independent definition of currency. Moreover, Part 2 of Art. 1 Federal Law No. 173-FZ states that the use of terms and concepts of civil, administrative and other branches of legislation of the Russian Federation is applied in the sense in which they are used in such branches of legislation. Therefore, the content of the term of "currency" may be qualitatively different in the civil, administrative and criminal legislation of the Russian Federation.

The Civil Code of the Russian Federation in a number of articles uses the terms "money (currency)", "payment instrument", "foreign currency" - Art. 140, "currency assets" - Art. 141, in other cases - "funds" - Art. 854, and so on.

At the same time, a citizen's money can also be in his bank accounts. With respect to a bank account statement, it is interesting to look at the ruling of the Supreme Court of the Russian Federation of April 26, 2016 No. 45-KG16-2, according to which the depositor indicated that the bankruptcy trustee refused to pay him an insurance benefit, citing non-receipt of the funds by the Bank at the time the contract was concluded. At the same time, the depositor was in possession of a receipt and cash warrant confirming the deposit of funds to the account opened with the bank.

The Supreme Court of the Russian Federation explained ${ }^{9}$ that in the context of Art. 140 of the Civil Code of the Russian Federation, technical records on a customer's accounts in a bank made in conditions of its insolvency cannot be considered as money, and they do not entail legal consequences in connection with the actual insolvency of the lending institution.

In the event that a certain bank is insolvent at the time the funds are deposited in the account and does not have sufficient funds to fulfill its obligations to creditors (which can be confirmed, for example, by a statement of account balances of the bank), the bank deposit contract cannot be recognized as signed. This situation entails the absence of an insured event. The funds in the form of an electronic statement of the owner's account will be recognized as such only when such a record was made at a time when the bank was solvent.

The Criminal Code of the Russian Federation uses the term "funds" and determines that they can be expressed in the form of a foreign currency or currency of the Russian Federation. Judicial practice distinguishes the money of the debt and the money of payment. In this case, the money of payment in the territory of the Russian Federation will always be expressed in Russian rubles. However, the money of the debt can be expressed in a foreign currency or conventional monetary units

9 Judicial Review of the Supreme Court of the Russian Federation № 42016 as approved by the Presidium of the Supreme Court of the Russian Federation 20 December 2016. Available at <http://www.vsrf.ru/Show_pdf.php?Id=11201>. [q. 2018-05-29]. 
with an indication in the contract that it is payable in rubles in an equivalent amount. ${ }^{10}$ Art. 200.1 of the Criminal Code of the Russian Federation also deals with the notion of a "monetary instrument", which according to Clause 5 of the note to this article means traveler's checks, bills of exchange, checks (bank checks), as well as securities in documentary form certifying the issuer's (debtor's) obligation to pay cash, in which the person to whom such payment is made is not specified.

Meanwhile, in accordance with "OK (MK (ISO 4217) 003-97) 014-2000. Russian Classifier of Currencies" (approved by Decree of the State Standard Office of Russia No. 405-st of 25. 12. 2000), the objects of classification of the Russian Classifier of Currencies are currencies, i.e., monetary units of countries and territories. ${ }^{11}$

Then, for the purposes of criminal law, funds mean in the form of foreign currency or currency of the Russian Federation, as well as monetary instruments in the form of traveler's checks, bills of exchange, checks (bank checks), securities in documentary form certifying the issuer's (debtor's) obligation for payment of funds, in which the person to whom such payment is made is not specified.

Accordingly, currency and currency assets are the subject of currency crimes, including those related to non-repatriation of funds, from the point of view of qualitative characteristics. But in addition to the qualitative aspect, the subject of currency crimes has a quantitative component, which is expressed by a specific amount in a note to the article to the Special Part of the Criminal Code of the Russian Federation.

The main object of currency crimes is public relations developing within the currency regime of the Russian Federation. These relations arise between an authorized bank and a legal entity and are associated with the return of currency assets to the territory of the Russian Federation. ${ }^{12}$

The objective side of a currency crime is non-repatriation by the head of an organization of a large amount of funds in foreign currency from abroad that are subject to compulsory transfer to accounts with an authorized bank in accordance with the legislation of the Russian Federation. Authorized banks are credit institutions that are established in accordance with the legislation of the Russian Federation and are entitled to carry out transactions with foreign currency on the basis of a license.

The subject of a currency crime is the head of the organization who has not repatriated the foreign currency from abroad.

The subjective side of a currency crime is direct intention, because the subject realized that he did not repatriate the foreign currency, and wanted this. ${ }^{13}$

Again, it should be mentioned that such obligation to repatriate funds from abroad currently does not exist in countries with developed market economies. On the contrary, modern countries strive to make capital movement free. In this sense, the experience of China is also of interest.

10 See: para 27 Ruling of the Plenum of the Supreme Court of the Russian Federation of 22 November 2016 № 54 “On certain matters of the application of general provisions of the Civil Code of the Russian Federation on obligations and the fulfillment thereof".

11 In Japan, the Bitcoin is recognized as legal tender along with the national currency. Australia even levies a tax on virtual currencies. Available at <http://www.coinfox.ru/novosti/zakonodatelstvo/5021-japanese-government-approves-newbitcoin-regulations-2>. [q. 2018-05-29]. However, this currency is neither a unit of a particular country, nor any territory. Despite this, a number of other countries (Denmark, Sweden) have stated that they will neither prohibit nor regulate the Bitcoin or other virtual currencies. See: LEJBA, A. Real Life of Virtual Money. In EZh-Yurist (2014), pp. 1, 4.

12 See: KONDRAT, E. Financial violations in Russia. The threat to financial security and how to counteract it. Moscow : FORUM publishers, 2014. 928 pp.

13 See: GAUKHMAN, L., MAKSIMOV, S. Criminal law protection of the financial environment: new types of crimes and their classification. Moscow, 1995. 96 pp. 
Foreign currency was mentioned for the first time in Chinese law in the Order on Strengthening Punishments for Persons Who Have Committed Serious Economic Crimes of 1982. However, amendments to the Criminal Code did not follow until 1988, when the illegal placement of foreign currency abroad was criminalized. Article 190 of the Criminal Code of China stated that any stateowned company, enterprise or any other state-owned unit that, against State regulations, deposits foreign currency outside China or illegally transfers foreign currency to any other countries shall, if the circumstances are serious, be fined, and the persons who report directly and other persons who are directly responsible for the crime shall be sentenced to fixed term imprisonment of no more than five years or criminal detention.

Today, the Criminal Code of China includes some other types of currency crimes, namely counterfeiting currency and securities. For example it provides different penalties for the following criminal activities: counterfeiting or altering a currently used coin, paper currency, or banknote with the intention to circulate; circulating a counterfeit or altered coin, paper currency, or banknote or collecting it from or delivering it to another with the intention to circulate; reducing the weight of a coin with the intention to circulate; circulating a coin of reduced weight or collecting it from or delivering it to another with the intention to circulate; manufacturing, delivering, or receiving an instrument or material with the intention of using it to counterfeit or alter a currently used coin, paper currency, or banknote or using it to reduce the weight of a currently used coin.

Undoubtedly, the experience of China is also of interest because of its new monetary policy concerning relationships with other countries. For example, between the Russian Federation and the People's Republic of China there is an agreement on mutual settlements in national currencies (RUB/ CNY) without using the USD as a transfer currency, which was reached in 2011 and confirmed in 2014. However, many issues still have to be resolved by both parties to the agreement. Thus, the USD is still a priority in many contracts between Russian and Chinese companies, etc. However, this trend in monetary policy of China cannot help but affect the global economy.

Today, globalism and modern international processes have such a strong influence on the modern world economy that the economic decisions of individual countries, regardless of their type, influence each other as well as the overall world development trend. Therefore, there is a need for common mechanisms to counter currency crimes. This is especially associated with the appearance and popularization of virtual currency.

\section{MODERN ISSUES OF CURRENCY REGULATION}

Along with the doctrinal problems of identifying, investigating and suppressing currency crimes for non-repatriation of funds from abroad, there is also uncertainty in the regulation of relations associated with the use of virtual currency in mutual settlements.

Given the urgency of counteracting currency crimes, in accordance with the order of the Prosecutor General of the Russian Federation, in March 2016 a working group was formed on the issues of repatriating from abroad assets obtained as a result of corrupt activities. Its main task is to organize interaction with competent Russian and foreign authorities for the return of such assets obtained as a result of corrupt activities. In addition, a National Contact Point (NCP) is operating under the 
Prosecutor General's Office, and is called upon to identify, seize, confiscate and return such assets through international channels. ${ }^{14}$

It is important to note that the NCP was created at the suggestion of the Ministry of Foreign Affairs within the framework of the UN Convention against Corruption and subject to the operations of the Prosecutor General's Office of the Russian Federation for coordination of the fight against corruption and cooperation with foreign countries on legal assistance in criminal matters, including recovery of assets received from criminal activity.

When an NCP is being created, the recommendations of the Open-ended Intergovernmental Working Group on Asset Recovery established by the Confederation of States Parties to the UN Convention against Corruption on the need for the NPC to form a unified network of such points are taken into account. Representatives of the Prosecutor General's Office of the Russian Federation take part in the meetings of this Intergovernmental Working Group.

The practical expediency of the activities of the NCP is to ensure the fastest and most effective interaction with the competent authorities of foreign states in the search for, confiscation and return of assets. Such contact points make it possible to resolve current issues of cooperation, including those related to the preparation and execution of requests for legal assistance.

The operation of the NCP is aimed at improving the effectiveness of monitoring and supervising compliance with the norms of legislation of the Russian Federation on currency regulation. In this case, the experience of Russia in this area may be of interest to Croatia, as our countries proclaim unified goals and principles of monetary policy.

This assertion is especially topical in connection with the increasing prevalence of virtual currency. Quite indicative in this regard is the June 17, 2016 event, when Ethereum (an analog of the Bitcoin) crypto currencies totaling about $\$ 50$ million disappeared from circulation for users. Although from the outside, this project seemed to be ideal, since distributed electronic money systems cannot be hacked. Therefore, people quietly invested their money, and in return received so-called tokens, which they used to vote for where to invest the total capital - the expected profit was supposed to be distributed among the participants of the initiative. However, the money suddenly appeared on the account of one of the project participants, who could not rightfully claim it, but he did not violate the terms of the contract. If this had happened in the real world, people could go to court or challenge the terms of the contract, contact the bank and ask to block the account. But these events occurred on the Internet, the invested money was calculated not in dollars, but in units of the distributed Ethereum ("ethers") crypto currencies. At the same time, the contract itself was of an innovative nature - it was a machine code that could not be changed without crashing the entire system; i.e., it was represented by a program that executed all the rules of the system when a transaction was made. ${ }^{15}$ In particular, it was also the fact that actions under an electronic contract were made not by people, but by computers. Therefore, it was almost impossible to break, cancel or bypass it, and if a participant wanted to leave the organization, a subsidiary organization was created to return the invested money, where funds were transferred from the main one. And as it turned out later, as a result of a mistake in the machine code, this operation could be repeated countless times, which was used to advantage by the attacker. In a short time, he transferred an amount equal to approximately $\$ 50$ million to his subsidiary organization. And this money could be returned only by the attacker

14 Available at <https://rns.online/economy/Genprokuratura-sozdala-spetsgruppu-po-vozvratu-zarubezhnih-aktivovkorruptsionerov-2016-03-28/>. [q. 2018-05-29].

15 Available at <https://lenta.ru/articles/2016/09/03/ethereum/>. [q. 2018-05-29]. 
himself, but he did not intend to do this, because he had not formally violated the terms of the contract. In the end, it turned out that there were no other participants of the project in the position to make claims and no one to apply for protection of their rights. As a result, it became obvious that the use of organizational and legal means to prevent such situations was more than relevant, and rules governed by self-executing smart contracts and decentralized (autonomous) organizations did not always work. It appears that the widespread use of this new decentralized technology will lead to an increase in the scope of new legislative regulation, which will determine the use of such rules. The features of such laws will most likely be determined by the fact that centralized authorities, such as government agencies and large multinational corporations, may lose the ability to monitor and shape the activities of individuals. ${ }^{16}$

This determines the need to focus on how to regulate and how to set up the creation and deployment of new decentralized organizations. And also on how to apply government regulations to combat money laundering via Bitcoin and similar virtual currencies. ${ }^{17}$

The use of a digital currency narrowing the relations between citizens and central banks and eliminating the need for the population to keep deposits in commercial banks may have profound consequences for the banking system. In particular, holders of crypto currencies can replace traditional shareholders, and can then appoint members of a governing body similar to a board of directors. This governing body can vote to issue the currency to the account holder, who can then act similarly to the chief financial officer to pay salaries to managers, employees and directors. ${ }^{18}$

At the same time, the anonymity in blockchain technology is preserved, in spite of the fact that the information about networks of chains is kept forever and its growing size, which works against anonymity. ${ }^{19}$ Ensuring effective management of blockchain technologies and smart contracts is essential to ensure its further evolution. Based on the mathematical principles underlying the location of the blocks, an alternative approach to existing legal practice is already being proposed. ${ }^{20}$ The so-called distributed jurisdiction is an open source platform ecosystem for reasonable resolution of contractual disputes, which allows users to select a conflict resolution mechanism by using crypto resources, as well as a mechanism for inherited enterprises that want to participate in the growth

16 WRIGHT, A., DE FILIPPI, P. Decentralized Blockchain Technology and the Rise of Lex Cryptographia, p. 4. Available at $<$ https://ssrn.com/abstract=2580664>. [q. 2018-05-29].

17 See: BRYANS, D. Bitcoin and Money Laundering: Mining for an Effective Solution, 2014, pp. $441-472$. Available at $<$ https://ssrn.com/abstract=2317990>. [q. 2018-05-29].

18 See: LEONHARD, R. Corporate Governance on Ethereum's Blockchain. Available at <https://ssrn.com/abstract$=2977522>$. [q. 2018-05-29].

19 It is often emphasized in legal doctrine how the Bitcoin can be used for illegal activities. "There are concerns about the secretive purchase of illegal goods and the cross-border transfer of money either for money-laundering or to finance terrorism (Ron \& Shamir, 2014; Tropina, 2014). Bitcoin was the normal means of settlement for the trade in illicit goods (such as drugs, pornography and weapons) via online marketplaces such as the infamous Silk Road (Christin, 2013). On the other hand, due to the pseudo-anonymous character of the currency, detection of criminals is not impossible, as demonstrated by the closure of Silk Road in October 2013 and the prosecution of its founder" (POLASIK, M., PIOTROWSKA, A., WISNIEWSKI, T., KOTKOWSKI, R., LIGHTFOOT, G. Price Fluctuations and the Use of Bitcoin: An Empirical Inquiry. Available at: <https://ssrn.com/abstract=2516754>. [q. 2018-05-29].) One of the most important regulatory developments has recently taken place in France. "While French authorities admit that Bitcoin does not pose a threat to financial markets, they have recognised that there is clearly room for concern with regards to criminal activity and fraud. These concerns are mostly concerned with the anonymity of transactions, which could have tax and money laundering implications" (GUADAMUZ, A., MARSDEN, Ch. Bitcoin: The Wrong Implementation of the Right Idea at the Right Time. Available at: <https://ssrn.com/abstract=2526736>. [q. 2018-05-29].).

20 KAAL, W., CALCATERRA, C. Crypto Transaction Dispute Resolution. Available at: <https://ssrn.com/abstract= 2992962>. [q. 2018-05-29]. 
of opportunities for crypto business and hope to avoid the inherited intermediary and transaction losses associated with it.

\section{$4 \quad$ CONCLUSION}

Today current international processes have such a strong influence on the modern world economy that the economic decisions of individual countries, regardless of their type, influence each other, as well as the overall world development trend. The ECB is now on the verge of abandoning the ultra-soft monetary policy in the direction of neutral and is further preparing for tightening. Since the ECB adheres to inflation targeting quite rigidly, and the trade and budget balance has long been in favor of the euro, discipline in monetary policy could turn into a new long-term trend of strengthening the euro. To achieve this goal, it is necessary not only to analyze the phenomenon of currency crimes and study the experience of combating currency crimes in other countries, but also evaluate common mechanisms to counter currency crimes, despite the economic type of a particular country.

\section{Bibliography:}

BLANPAIN, R., ENGELS, C. (eds.). Comparative Labour Law and Industrial Relations in Industrialized Market Economies. The Hague : Kluwer Law International, 2001.

BRYANS, D. Bitcoin and Money Laundering: Mining for an Effective Solution. In Ind. L.J., 89, 441 (2014).

GAUKHMAN, L.D., MAKSIMOV, S.V. Criminal law protection of the financial environment: new types of crimes and their classification. Moscow, 1995.

GUADAMUZ, A., MARSDEN, C. Bitcoin: The Wrong Implementation of the Right Idea at the Right Time, 2014. Available at: <https://ssrn.com/abstract=2526736 >. [q. 2018-05-29].

DONG, H., MCCAULEY, R. N. Offshore Markets for the Domestic Currency: Monetary and Financial Stability Issues. BIS Working Paper No. 320, 2010. Available at: <https://ssrn.com/abstract=1699740>. [q. 2018-05-29].

KONDRAT, E. N. Financial violations in Russia. The threat to financial security and how to counteract it. Moscow: FORUM publishers, 2014.

KAAL, W., CALCATERRA, C. Crypto Transaction Dispute Resolution, 2017. Available at: <https://ssrn.com/abstract $=2992962>$. [q. 2018-05-29].

KUCHEROV, I.I. Currency Law of Russia (Academic Lecture Course), 2011.

LEJBA, A. Real Life of Virtual Money. In EHZH-YUrist., № 23 (2014).

LEONHARD, R. Corporate Governance on Ethereum's Blockchain, 2017. Available at: <https://ssrn.com/abstract=2977522>. [q. 2018-05-29].

LEVKOVICH, A., VECHERSKY, A. Analysis of the evolution of the exchange rate policy in the countries of Central and Eastern Europe. In Bankauski Vesnik, № 10 (2008).

POLASIK, M., PIOTROWSKA, A., WISNIEWSKI, T., KOTKOWSKI, R., LIGHTFOOT, G. Price Fluctuations and the Use of Bitcoin: An Empirical Inquiry, 2014. Available at: <https://ssrn.com/abstract=2516754>. [q. 2018-05-29].

RASKIN, M., YERMACK, D. Digital Currencies, Decentralized Ledgers, and the Future of Central Banking. In Research Handbook on Central Banking. Cheltenham : Edward Elgar, 2016.

SALVATORE, D., RENGIFO, E.W., OZSOZ, E. Dollarization as an Investment Signal in Developing Countries: The Case of Croatia, Czech Republic, Peru, Slovak Republic and Turkey. In Fordham University Department of Economics Discussion Paper, No. 2008-16 (2008). 
WRIGHT, A., DE FILIPPI, P. Decentralized Blockchain Technology and the Rise of Lex Cryptographia, 2015. Available at: <https://ssrn.com/abstract=2580664>. [q. 2018-05-29].

\section{Contact information}

prof. Oleg A. Stepanov, Dr.

crim@izak.ru

The Institute of Legislation and Comparative Law under the Government of the Russian Federation, Department of Criminal,

Criminal Procedural Law; Judicial System

117218, B. Cheremushkinskaya 34

Moscow

The Russian Federation

Denis A. Pechegin, Ph.D.

crim5@izak.ru

The Institute of Legislation and Comparative Law under the Government of the Russian Federation, Department of Criminal,

Criminal Procedural Law; Judicial System

117218, B. Cheremushkinskaya 34

Moscow

The Russian Federation 